\title{
MODEL PEMIDANAAN YANG IDEAL BAGI KORBAN PENGGUNA NARKOBA DI INDONESIA
}

\author{
Parasian Simanungkalit Dewan \\ Pimpinan Nasional Gepenta Email: \\ parsim1945@yahoo.com
}

\begin{abstract}
The purpose of this research is to determine the ideal model of punishment for the victims of drug users in Indonesia as a guide law enforcement in dealing with drug abuse crimes. This research is doctrinal and non-doctrinal legal. The research data used primary and secondary data. Secondary data consists of primary, secondary and tertiary legal materials.. Data collecting technique include observation, in-depth interviews, focus group discussions, distributing questionnaires, and literature. Technique of data analysis used the method of qualitative analysis and normative models of interactive analysis. The results of the research indicate that the implementation of imprisonment for the victims of drug users under the Act of Narcotics which are classified into criminal, contrary to the legal theory of victimology. Model of punishment that is expected for the victims of drug users is extrajudicial process, means all victims of drug users reported themselves to be rehabilitated. While those who do not report, the police and/ or BNN arrest, immediately deliver and turn over to rehabilitation.
\end{abstract}

Keywords: victims of drug users, model of punishment, rehabilitation.

\begin{abstract}
Abstrak
Penelitian ini bertujuan untuk menentukan model pemidanaan yang ideal bagi korban pengguna narkoba di Indonesia sebagai pedoman aparat penegak hukum dalam menangani kejahatan penyalahgunaan narkoba. Penelitian ini merupakan penelitian hukum doktrinal dan nondoktrinal. Data yang digunakan berupa data primer dan data sekunder. Data sekunder terdiri atas bahan hukum primer, sekunder dan tertier. Teknik pengumpulan data meliputi observasi, wawancara mendalam, focus group discussion, penyebaran kuesioner, dan studi pustaka. Teknik analisis data menggunakan metode analisis normatif kualitatif dan model analisis interaktif. Hasil penelitian menunjukkan bahwa penerapan hukuman pidana penjara bagi korban pengguna narkoba menurut Undang-Undang Narkotika yang diklasifikasi sebagai pelaku tindak pidana bertentangan dengan teori hukum tentang viktimologi. Model pemidanaan yang ideal bagi korban pengguna narkoba adalah proses di luar proses hukum yaitu semua korban pengguna narkoba melaporkan diri untuk direhabilitasi. Sementara bagi yang tidak melaporkan diri, polisi dan/atau Badan Narkotika Nasional (BNN) melakukan penangkapan, langsung diantar dan diserahkan ke tempat rehabilitasi

Kata kunci: korban pengguna narkoba, model pemidanaan, rehabilitasi.
\end{abstract}

\section{A. Pendahuluan}

Dunia semakin tidak kondusif dengan permasalahan sosial akibat penggunaan narkoba ilegal. Secara global, United Nation on Drugs and Crime (UNODC) memperkirakan antara 155 sampai 250 juta orang atau 3,5-5,7 persen dari penduduk dunia usia 15-64 tahun menggunakan zat terlarang setidaknya sekali pada 2008 (Parasian Simanungkalit, 2011 : 86). Dalam hal ini, penulis memilih istilah narkotika dan psikotropika dengan sebutan narkoba, meskipun istilah narkoba tidak terdapat dalam Undang Undang. Hal tersebut dikarenakan istilah narkoba dipakai oleh instansi kepolisian dalam praktek dan lebih dikenal masyarakat secara umum.

Akhir-akhir ini permasalahan penyalahgunaan narkoba di Indonesia tidak menurun, namun justru semakin kompleks. Peningkatan dimaksud terbukti dengan meningkatnya jumlah pengguna, maupun pengedar yang tertangkap, serta diungkapnya sindikasi pabrik narkoba oleh BNN yang ternyata dibangun di Indonesia. Beberapa kejadian yang disebabkan akibat penyalahgunaan narkoba juga menjadikan masyarakat merasa prihatin, seperti halnya kecelakan mobil xenia oleh Afriyani yang mengakibatkan sembilan orang meninggal, tertangkapnya pilot mengonsumsi sabu-sabu, serta oknum kepolisian yang diketahui sebagai pengguna narkoba. Hal tersebut merupakan beberapa contoh kasus yang meresahkan masyarakat.

Sejalan semakin meningkatnya penyalahgunaan narkoba, pemerintah telah mengupayakan menindak tegas para sindikat dan pengedar dengan memberikan hukuman berat, bahkan sampai hukuman mati. Adapun bagi korban pengguna atau pecandu, pemerintah telah mengupayakan untuk 
mengurangi dampak buruk akibat penggunaan narkoba yaitu dengan cara memberikan fasilitas rehabilitasi, baik secara medis maupun sosial. Hal ini dilakukan agar korban pengguna narkoba dapat kembali sembuh, menjadi manusia produktif, mampu bekerja memenuhi kebutuhan kehidupan serta keluarganya, dan menjadi generasi bangsa yang sehat dan kuat.

Namun kebijakan untuk menempatkan korban pengguna narkoba di tempat rehabilitasi tidak dapat berjalan secara baik karena masih terbentur dengan ketentuan Undang Undang Narkotika yang dalam hal ini korban pengguna narkoba sampai sekarang ini masih diposisikan sebagai pelaku tindak pidana, akibatnya mereka tidak memperoleh perawatan dan pemulihan secara maksimal karena harus mendekam di dalam penjara.

Padahal jika dicermati dengan seksama, khususnya dari perspektif medis, banyak ahli berpendapat bahwa sebenarnya para individu pengguna narkoba merupakan korban sindikat atau mata-rantai peredaran dan perdagangan gelap narkoba yang sulit melepaskan diri dari ketergantungan. Walaupun mungkin sebenarnya para pengguna tersebut ingin lepas dari jeratan narkoba yang membelitnya, namun karena syarafnya sudah teracuni candu oleh zat adiktif maka hal itu sulit dilakukan. Oleh karena itu, pengguna atau pecandu memerlukan penanganan yang berbeda dari pasien pada umumnya.

Menurut perspektif yuridis, pengguna narkoba tidak dapat dikategorisasikan sebagai pelaku kejahatan karena sifat dasar kejahatan haruslah menimbulkan korban dan korban itu adalah orang lain (an act must take place that involves harm inflicted on someone by the actor). Pandangan inilah yang kemudian mengarahkan pada pemahaman bahwa pengguna narkoba merupakan salah satu bentuk dari kejahatan tanpa korban (crime without victim). Hal itu berarti apabila hanya diri sendiri yang menjadi korban, maka hal tersebut tidak dapat dikatakan sebagai kejahatan, sehingga tidak dapat dihukum.

Dalam konteks pemidanaan korban penyalahgunaan narkoba, permasalahan muncul ketika ancaman pidana yang dirumuskan pemerintah bersama Dewan Perwakilan Rakyat (DPR-RI) dan telah disahkan menjadi Undang-Undang Nomor 5 Tahun 1997 tentang Psikotropika (selanjutnya disebut UU Psikotropika) dan Undang-Undang Nomor 22 Tahun 1997 tentang Narkotika yang kemudian diubah menjadi Undang-Undang Nomor 35 Tahun 2009 tentang Narkotika (selanjutnya disebut UU Narkotika), masih terdapat kontradiksi, kerancuan, ketidaksesuaian, dan juga keragamaan dalam menerapkan produk hukum tersebut, terutama dalam menentukan sanksinya. Di satu sisi, pengguna narkoba dipidana penjara, di sisi lain direhabilitasi. Meskipun Undang Undang telah menyebutkan secara jelas bahwa korban pengguna narkoba berhak menjalani pengobatan dan/atau perawatan melalui rehabilitasi, namun pada kenyataannya jarang sekali hakim memilih menjatuhkan hukuman rehabilitasi. Berdasar fakta, walau diwajibkan untuk merehabilitasi tetapi pemidanaan yang diterapkan terhadap korban pengguna narkoba masih berupa pidana penjara.

Dalam perkembangannya Mahkamah Agung telah mengeluarkan Surat Edaran Nomor 04 Tahun 2010 tentang Penempatan Penyalahgunaan, Korban Penyalahgunaan, dan Pecandu Narkotika ke dalam lembaga rehabilitasi medis dan sosial yang menjadi pegangan hakim pengadilan negeri dan pengadilan tinggi dalam memutus perkara. Selain itu, pada tahun 2011 lahir Peraturan Pemerintah Nomor 25 Tahun 2011 tentang Pelaksanaan Wajib Lapor Pecandu Narkotika, memberikan jaminan kepada pecandu dan/atau korban penyalahgunaan narkotika untuk mendapatkan pengobatan dan/atau perawatan melalui rehabilitasi medis dan rehabilitasi sosial. Kedua peraturan tersebut merupakan langkah maju dalam membangun paradigma penghentian kriminalisasi atau dekriminalisasi terhadap pecandu narkoba. Penerapan hukuman pidana (penjara) bagi korban pengguna narkoba di Indonesia terbukti tidak dapat menurunkan jumlah penyalahguna, bahkan setiap tahunnya mengalami peningkatan.

Berdasarkan latar belakang tersebut di atas, maka permasalahan yang dapat dikaji adalah bagaimana model pemidanaan yang ideal bagi korban pengguna narkoba di Indonesia sebagai pedoman aparat penegak hukum dalam menangani kejahatan penyalahgunaan narkoba?

\section{B. Metode Penelitian}

Penelitian ini menggunakan dua jenis penelitian hukum yakni doktrinal dan non doktrinal, menggunakan bentuk diagonistik dan preskriptif. Hukum dikonsepkan sebagai norma-norma positif di dalam sistem perundang-undangan hukum nasional dan hukum sebagai manifestasi maknamakna simbolik para pelaku sosial sebagai tampak dalam interaksi antar anggota masyarakat. Lokasi penelitian ditentukan secara purposive yaitu di Pengadilan Negeri Jakarta Selatan, Pengadilan Negeri Medan Sumatera Utara, Program Terapi Rumatan Metadon Puskesmas Kelurahan Rawa Badak Selatan Jakarta Utara, Rumah Sakit Ketergantungan Obat (RSKO) Halmahera House Jakarta Timur, dan Lembaga Pemasyarakatan Cipinang Jakarta Timur. Data yang digunakan berupa data primer dan data sekunder. Data sekunder 
meliuputi bahan hukum primer, sekunder dan tertier. Teknik pengumpulan data meliputi observasi, wawancara mendalam, focus group discussion, kuesioner, dan studi pustaka. Pada pendekatan doktrinal, analisis dilakukan dengan menggunakan metode analisis normatif kualitatif, sedangkan pada pendekatan non doktrinal, analisis yang dilakukan dengan menggunakan analisis kualitatif yang dilakukan menggunakan model analisis interaktif.

\section{Hasil Penelitian dan Pembahasan}

\section{Tahapan Pemakaian Narkoba}

Ada beberapa tahapan dan pola pemakaian narkoba secara tidak sah, sehingga menyebabkan ketergantungan atau kecanduan, yang dibedakan dalam lima tahap perkembangan (Howard Abadinsky, 2008 : 240) yaitu 1) pola coba-coba (experimental use). Pada tahapan ini, pengaruh kelompok sebaya memang sangat besar seperti teman dekat atau orang lain yang menawarkan untuk menggunakan narkoba. 2) pola pemakaian sosial (social use). Pola pemakaian sosial yaitu pemakaian narkoba untuk kepentingan pergaulan dan keinginan untuk diakui oleh kelompoknya. 3) Pola pemakaian situasional (situational use). Pada tahap ini biasanya pengguna akan berusaha untuk mengkonsumsi secara aktif. 4) Pola habituasi (penyalahgunaan/abouse). Pada tahap ini pemakaian akan sering dilakukan dan umumnya pada tahapan inilah terjadinya proses ketergantungan. 5) Pola ketergantungan (compulsive depandent use). Pengguna tidak lagi mampu mengendalikan dirinya sebab narkoba telah menjadi pusat kehidupannya.

Sementara itu ada tiga alasan yang menjadi motivasi seseorang menggunakan narkoba (Aaron T. Beck, 1993 : 35) : 1) anticipatory beliefs, yakni para pelaku yang menggunakan narkoba dengan tujuan mendapatkan pengakuan dalam status tertentu. 2) relieving beliefs, yakni para pelaku yang menggunakan narkoba untuk menghilangkan perasaan kecewa, sedih, marah, putus asa, tegang dan perasaan lain yang tidak menyenangkan. 3) permissive beliefs atau facilitative beliefs, yakni para pelaku yang menggunakan narkoba sebagai perbuatan yang menurut nilai-nilai yang pelaku anut bukan merupakan perbuatan yang melanggar norma.

\section{Kedudukan Korban dalam Sistem Peradilan Pidana}

Dalam perspektif viktomologi, terutama mengenai tipologi korban, terdapat beberapa pendapat ahli hukum mengenai korban penyalahgunaan narkoba. Ditinjau dari perspektif tingkat keterlibatan korban dalam terjadinya kejahatan, pengertian korban penyalahgunaan narkoba menurut Ezzat Abdul Fateh (dalam J.E. Sahetapy, 1995 : 14-125), termasuk dalam tipologi False Victims yaitu pelaku yang menjadi korban karena dirinya sendiri.

Merujuk perspektif tanggung jawab korban, adanya self-victimizing victims yakni pelaku yang menjadi korban karena kejahatan yang dilakukannya sendiri. Hal ini sering dinyatakan sebagai kejahatan tanpa korban (Dikdik M. Arief Mansur dan Elisatris Gultom, 2007 : 125). Akan tetapi, pandangan ini menjadi dasar pemikiran bahwa tidak ada kejahatan tanpa korban. Semua atau setiap kejahatan melibatkan 2 (dua) hal, yaitu penjahat dan korban. Sebagai contoh dari self-victimizing victims adalah pecandu obat bius, alkoholisme, homoseks, dan judi. Hal ini berarti pertanggungjawaban terletak penuh pada si pelaku, yang juga sekaligus merupakan korban.

Menurut Sellin dan Wolfgang, korban penyalahgunaan narkoba merupakan "mutual victimization", yaitu pelaku yang menjadi korban adalah si pelaku sendiri. Seperti halnya pelacuran, perzinahan, dan narkoba (Dikdik M. Arief Mansur dan Elisatris Gultom, 2007 : 206207).

Berdasarkan beberapa pendapat para ahli hukum mengenai tipologi korban dalam perpektif viktimologi dapat dinyatakan bahwa pecandu narkoba merupakan self-victimizing victims, yaitu seseorang yang menjadi korban karena perbuatannya sendiri. Namun, ada juga yang mengelompokkannya dalam victimless crime atau kejahatan tanpa korban karena kejahatan ini biasanya tidak ada sasaran korban, semua pihak terlibat (Dikdik M. Arief Mansur dan Elisatris Gultom, 2007 : 49-51). Selain itu, pecandu narkoba dapat juga dikategorikan sebagai kejahatan tanpa korban (crime without victim). Pengertian kejahatan tanpa korban berarti kejahatan ini tidak menimbulkan korban sama sekali akan tetapi si pelaku sebagai korban. Sementara dalam katagori kejahatan, suatu perbuatan jahat haruslah menimbulkan korban dan korban itu adalah orang lain (an act must take place that involves harm inflicted on someone by the actor). Artinya apabila hanya diri sendiri yang menjadi korban maka hal tersebut tidak dapat dikatakan sebagai kejahatan. 
Tindak pidana atau perbuatan melawan hukum dilakukan oleh seseorang kepada orang lain, kalau tidak ada pihak lain yang menjadi korban maka sebagaimana diputuskan Mahkamah Konstitusi melalui Putusan Nomor 1/PUU-IX/2011, tidaklah dapat dikatakan sebagai tindak pidana atau delik (delict) karena sifat umum tindak pidana adalah perbuatan melawan hukum yaitu perbuatan yang melanggar norma sedemikian rupa sehingga mencederai kepentingan hukum orang lain atau membahayakan kepentingan orang lain. Putusan pengadilan Mahkamah Konstitusi ini diambil untuk menguatkan pendapat para pakar hukum sekaligus meyakinkan peneliti bahwa korban karena perbuatannya sendiri bukanlah suatu tindak pidana. Dengan demikian, seseorang yang menggunakan narkoba untuk dirinya sendiri dan perbuatan tersebut tidak merugikan dan/ atau menyebabkan terjadinya korban, maka pengguna tersebut tidak dapat dikatagorisasikan sebagai perbuatan kejahatan.

\section{Tujuan Hukum Pidana sebagai Upaya Penanggulangan Kejahatan}

Menurut Moeljatno, sebagaimana dikutip Tongat (Tongat, 2008 : 14), menyatakan bahwa hukum pidana adalah bagian keseluruhan hukum yang berlaku di suatu negara, yang mengadakan dasar-dasar atau aturan-aturan untuk: a. menentukan perbuatan-perbuatan mana yang tidak boleh dilakukan, yang dilarang, dengan disertai ancaman atau sanksi yang berupa pidana tertentu bagi siapa yang melanggar larangan tersebut; b. menentukan kapan dan dalam hal-hal apa pelaku yang telah melanggar larangan-larangan itu dapat dikenakan atau dijatuhi pidana sebagaimana yang telah diancamkan; c. menentukan dengan cara bagaimana pidana itu dapat dilaksanakan apabila ada orang yang disangka telah melanggar larangan tersebut.

Sifat pidana sebagai "ultimum remedium" menghendaki agar jangan menggunakan pidana sebagai sarana apabila tidak perlu sekali. Sebab pidana tidak hanya dirasa tidak enak pada waktu dijalani, tetapi sesudah itu orang yang dikenai itu masih merasakan akibatnya yang berupa "cap" oleh masyarakat bahwa ia pernah berbuat "jahat". Cap ini dalam ilmu pengetahuan disebut "stigma". Jadi orang tersebut mendapatkan stigma; dan kalau tidak hilang maka ia seolah-olah dipidana seumur hidup (Soedarto : 2007 : 24).

Tujuan pidana biasa disingkat dengan istilah 3R dan 1D. 3R itu ialah Reformation,
Restraint, dan Restribution. 1D ialah deterrence yang terdiri atas individual deterrence dan general deterrence (pencegahan khusus dan pencegahan umum) (Abidin Az dan Andi Hamzah, 2010 : 42-43). Reformasi (reformation) berarti memerbaiki atau merehabilitasi penjahat menjadi orang baik dan berguna bagi masyarakat. Restraint maksudnya ialah mengasingkan pelanggar dari masyarakat. Restribution ialah pembalasan terhadap pelanggar karena telah melakukan kejahatan. Sekarang ini banyak dikritik sebagai sistem yang bersifat barbar dan tidak sesuai dengan masyarakat yang beradab.

\section{Ketentuan Sanksi Pidana dan Upaya Rehabilitasi}

Pada dasarnya penjatuhan sanksi pidana penjara terhadap korban pengguna narkoba tidak dapat mengubah perbuatannya sebagai pengguna narkoba karena pelaku adalah orang yang kecanduan, menderita kesakitan yang seharusnya mendapat pengobatan dan perawatan. Namun karena perbuatan tersebut telah ditetapkan sebagai perbuatan melanggar hukum, dan telah ditetapkan dalam Undang Undang Narkotika, maka perbuatan tersebut dapat dikenakan sanksi pidana. Hal ini sesuai asas legalitas yang tercantum dalam Pasal 1 ayat (1) KUHP, yakni tidak dapat dipidana seseorang kecuali atas perbuatan yang dirumuskan dalam suatu aturan perundangundangan yang telah ada terlebih dahulu (nullum delictum nula poena sine praevia lege poenali).

Pengaturan sanksi pidana terhadap pengguna narkoba bagi diri sendiri terdapat dalam Pasal 127 UU Narkotika. Menggunakan narkoba bagi diri sendiri mengandung maksud bahwa penggunaan tersebut dilakukan tanpa melalui pengawasan dokter. Penggunaan narkoba tanpa melalui pengawasan dokter tersebutlah yang merupakan suatu perbuatan "tanpa hak dan melawan hukum". Artinya, selama peraturan perundang-undanganya masih mencantumkan ancaman pidana penjara bagi pengguna narkoba meskipun bagi dirinya sendiri maka hukuman tersebut akan selalu ada. Atas dasar itulah, pengguna atau pecandu narkoba dapat dipidanakan.

Meskipun demikian, UU Narkotika juga mengatur tentang rehabilitasi bagi pengguna atau pecandu, yakni terdapat dalam Pasal 54 , Pasal 55, Pasal 56, Pasal 57, Pasal 58 dan Pasal 103. Di dalam Pasal 103 UU Narkotika, menyebutkan hakim yang memeriksa perkara pecandu narkoba dapat melakukan dua hal. 
Pertama, hakim dapat memutuskan untuk memerintahkan yang bersangkutan menjalani pengobatan dan/atau perawatan apabila pecandu narkoba tersebut terbukti bersalah melakukan tindak pidana narkoba. Kedua, hakim dapat menetapkan untuk memerintahkan yang bersangkutan menjalani pengobatan dan/atau perawatan, apabila pecandu narkoba tersebut tidak terbukti bersalah melakukan tindak pidana narkoba.

Pecandu narkoba yang terbukti bersalah disebutkan hakim "dapat" memutus untuk memerintahkan yang bersangkutan menjalani pengobatan dan/atau perawatan melalui rehabilitasi. Namun demikian, dalam ketentuan Pasal 54, menyebutkan pecandu narkotika dan korban penyalahgunaan narkotika "wajib" menjalani rehabilitasi medis dan rehabilitasi sosial, maka konsekuensinya mau tidak mau putusan yang dijatuhkan haruslah memerintahkan yang bersangkutan menjalani rehabilitasi. Dengan kata lain, putusan yang dijatuhkan hakim bagi pecandu atau pengguna narkoba bagi diri sendiri tidak lagi mengandung multitafsir yang terdapat dalam kata "dapat", harusnya dibaca "wajib".

Undang Undang Narkotika juga memberikan landasan hukum kemungkinan pengguna narkotika tidak dipidana, sebagaimana diatur Pasal 128 ayat (2) dan (3) UU Narkotika, yang memberikan jaminan tidak dituntut pidana dengan kriteria sebagai berikut.

a. Pecandu narkotika yang belum cukup umur dan telah dilaporkan oleh orang tua atau walinya sebagaimana dimaksud dalam Pasal 55 ayat (1) tidak dituntut pidana

b. Pecandu narkotika yang telah cukup umur sebagaimana dimaksud dalam Pasal 55 ayat (2) yang sedang menjalani rehabilitasi medis 2 (dua) kali masa perawatan dokter di rumah sakit dan/atau lembaga rehabilitasi medis yang ditunjuk oleh pemerintah tidak dituntut pidana.

Dilihat dari ketentuan tersebut jelas bahwa pengguna narkoba tidak dipidana, karena pengguna narkoba terutama yang dalam tahap kecanduan adalah didudukkan sebagai korban yang sepatutnya direhabilitasi, baik secara medis maupun sosial. Hal ini sesuai Pasal 54 UU Narkotika. Sejalan dengan ketentuan tersebut, pada 2010, Mahkamah Agung RI kembali mengeluarkan Surat Edaran (SEMA) Nomor 4 Tahun 2010 Tentang Penempatan Penyalahgunaan, Korban Penyalahgunaan, dan Pecandu Narkotika ke dalam Lembaga Rehabilitasi Medis dan Sosial. Dalam Butir 3 SEMA Nomor 4 Tahun 2010 disebutkan "Dalam hal hakim menjatuhkan pemidanaan berupa perintah untuk dilakukan tindakan hukum berupa rehabilitasi atas diri terdakwa, Majelis Hakim harus menunjuk secara tegas dan jelas tempat rehabilitasi yang terdekat dalam amar putusannya". bahwa:

Hal tersebut berdasarkan pertimbangan

1) sebagian besar narapidana dan tahanan kasus narkotika termasuk dalam kategori pemakai atau bahkan sebagai korban jika dilihat dari aspek kesehatan pelaku sesungguhnya orang-orang yang menderita sakit, oleh karena itu memenjarakan yang bersangkutan bukanlah langkah yang tepat karena telah mengabaikan kepentingan perawatan dan pengobatan;

2) kondisi Lembaga Pemasyarakatan (LP) yang tidak mendukung. Dampak negatif keterpengaruhan oleh perilaku kriminal lainnya dapat semakin memperburuk kondisi kejiwaan dan kesehatan yang diderita para narapidana narkotika.

Artinya, ketika hakim memeriksa kasus narkoba dengan spesifikasi jumlah barang bukti sebagaimana terdapat dalam ketentuan SEMA Nomor 4 Tahun 2010 maka hakim sudah seharusnya tidak ragu untuk segera memutuskan agar menempatkan terdakwa korban pengguna narkoba di dalam lembaga rehabilitasi medis dan sosial, sebagaimana diamanatkan Mahkamah Agung kepada semua Pengadilan Negeri.

Sebagai upaya pelaksanaan rehabilitasi, selain pemerintah Indonesia mempunyai tugas dan tanggungjawab dalam menyelenggarakan upaya kesehatan bagi rakyat melalui perpanjangan tangan dari Menteri Kesehatan dan Menteri Sosial, pihak swasta juga dapat berperan aktif dalam penyelenggaraan rehabilitasi. Akan tetapi pihak swasta yang menyelenggarakan rehabilitasi harus mengikuti pedoman standarisasi yang dikeluarkan oleh Menteri Kesehatan melalui KEPMENKES 996/ MENKES/SK/VIII/2002 tentang Pedoman Penyelenggaraan Sarana Pelayanan Rehabilitasi Penyalahgunaan dan Ketergantungan NAPZA dan Peraturan Menteri Sosial Nomor 56/HUK/2009 tentang Pelayanan dan Rehabilitasi Sosial Korban Penyalahgunaan Narkotika, Psikotropika dan Bahan Adiktif Lainnya. 
Ketentuan hukum lainnya dalam menempatkan korban pengguna narkoba di tempat rehabilitasi medis dan sosial juga tertuang dalam Peraturan Pemerintah Nomor 25 Tahun 2011 Tentang Pelaksanaan Wajib Lapor Pecandu Narkotika. Berdasarkan peraturan pemerintah tersebut memberikan jaminan kepada pecandu dan/atau korban penyalahgunaan narkoba untuk mendapatkan pengobatan dan/atau perawatan melalui rehabilitasi medis dan rehabilitasi sosial. Peraturan Pemerintah Nomor 25 Tahun 2011 merupakan turunan Pasal 54 dan Pasal 55 UU Narkotika. Pasal 54 menyebutkan pecandu narkotika dan korban penyalahgunaan narkotika wajib menjalani rehabilitasi medis dan rehabilitasi sosial, sedangkan Pasal 55 ayat (1) menjelaskan orang tua atau wali dari pecandu narkotika yang belum cukup umur wajib melaporkan kepada pusat kesehatan masyarakat, rumah sakit, dan/atau lembaga rehabilitasi medis dan rehabilitasi sosial yang ditunjuk oleh pemerintah untuk mendapatkan pengobatan dan/atau perawatan melalui rehabilitasi medis dan rehabilitasi sosial. Pasal 55 ayat (2) bagi pecandu narkotika yang sudah cukup umur wajib melaporkan diri atau dilaporkan oleh keluarganya kepada pusat kesehatan masyarakat, rumah sakit, dan/atau lembaga rehabilitasi medis dan rehabilitasi sosial yang ditunjuk oleh pemerintah untuk mendapatkan pengobatan dan/atau perawatan melalui rehabilitasi medis dan rehabilitasi sosial.

Menurut pengamat hukum, Simplexius Asa, UU Narkotika hanya menempatkan pengguna narkoba sebagai pelaku tindak kriminal, termasuk keluarga dan temannya. Pengguna narkoba, menurut Simplex, berbeda dengan koruptor karena pengguna narkoba melakukan kejahatan untuk dirinya sendiri. Sedangkan koruptor sudah mengambil hak orang lain. Simplex menyimpulkan, pengguna narkoba bukan pelaku tindak kriminal sehingga tidak dilakukan vonis pemenjaraan (http:// www.satuportal.net).

Dikeluarkanya SEMA Nomor 4 Tahun 2010 telah memberikan sebuah panduan bagi hakim untuk menempatkan pecandu narkoba ke dalam lembaga rehabilitasi medis dan sosial. Adapun yang menjadi pokok pertimbangan adalah ruh atau semangat dari UU Narkotika adalah mengakui pecandu narkoba sebagai pesakitan dan melindungi pecandu narkoba dan korban penyalahgunaan narkoba tersebut dengan menempatkannya di lembaga medis dan sosial (A.R. Sujono dan Boni Daniel, 2011 :127).

Dengan menelaah penjelasan di atas, institusi dan penegak hukum di Indonesia sebaiknya mulai memilih jalur alternatif yakni melalui vonis rehabilitasi bagi pengguna narkoba. Vonis pidana dengan pemenjaraan terhadap korban pengguna narkoba bukan solusi efektif karena pengguna narkoba merupakan korban dari kejahatan peredaran gelap narkoba.

Hasil penelitian yang dilakukan penulis, menunjukkan bahwa selama pengguna narkoba di penjara para pelaku masih bisa mengkonsumsi narkoba secara sembunyisembunyi yang di dapat secara ilegal. Sementara dari segi medis, pidana penjara bukanlah tempat yang baik bagi proses penyembuhan ketergantungan obat, namun justru akan semakin menyiksa mental pelaku. Disamping tidak efektif, vonis penjara dalam perspektif manajemen penyelenggaraan negara dapat dikatakan merugikan pemerintah. Dapat dikalkulasikan, berapa dana yang harus dikeluarkan pemerintah untuk memberikan kebutuhan makan bagi warga binaan narkoba di dalam lembaga pemasyarakatan. Selain itu, negara juga tidak dapat memberikan jaminan tempat yang layak di lembaga pemasyarakatan. Hampir semua LP Narkotika di Indonesia penuh sesak. Akibatnya, penghuni harus berdesak-desakan dan tidak jarang, karena kondisi yang serba minim, mudah terjadi kekerasan di dalam penjara. Belum lagi mengkriminalkan pengguna narkoba justru menjadikan upaya penanggulangan penularan HIVIAIDS menjadi terhambat, dan bagi pengguna akan mendapat stereotif negatif dari masyarakat ketika ke luar dari penjara.

\section{Model Pemidanaan Ideal bagi Korban Pengguna Narkoba}

Pada kasus penyalahgunaan narkoba di Indonesia, korban pengguna narkoba yang tertangkap menggunakan narkoba langsung dimasukkan ke rumah tahanan negara (rutan) atau sel polisi. Kemudian untuk mengembangkan penyidikan, korban tersebut masih tetap berada dalam rutan. Ketika dalam proses penyidikan sudah terkumpul bukti-bukti yang menguatkan, maka penyidik akan mengirim Berkas Acara Pemeriksaan (BAP) kepada kejaksaan untuk kemudian kejaksaan membentuk penuntut umum yang kemudian membuat surat dakwaan dan diajukan pada pengadilan negeri. Pada saat proses ini 
berlangsung korban pengguna narkoba dipindahkan dari rutan polri ke rutan kejaksaan, atau rutan pada lembaga pemasyarakatan (LP). Ketua pengadilan yang telah menerima surat dakwaan dari kejaksaan, kemudian membentuk majelis hakim yang bertugas memanggil terdakwa. Perkara tersebut kemudian disidangkan di pengadilan negeri, dan korban pengguna narkoba yang telah berstatus sebagai terpidana langsung menjalani hukuman di LP.

Model pemidanaan, sebagaimana dijelaskan di atas, dengan cara menempatkan korban pengguna narkoba dalam tahanan (meskipun dalam ketentuan mendapat hak pengobatan/perawatan) sejatinya akan mempersulit korban pengguna narkoba untuk dapat sembuh dari ketergantungan. Apalagi kondisi LP yang tidak mendukung akan berdampak negatif dan semakin memperburuk kondisi kejiwaan dan kesehatan yang diderita oleh narapidana pengguna narkoba.

Penjatuhan pidana penjara kepada korban pengguna narkoba sebelum Undang-Undang Narkotika dirubah karena telah ada terobosan hukum, maka penjatuhan sanksi pidana kepada korban pengguna narkoba tidak dipidana penjara tetapi dalam amar putusan hakim dapat memerintahkan untuk ditempatkan di tempat rehabilitasi. Adapun model pemidanaan yang diharapkan yakni seseorang yang kedapatan menggunakan narkoba bagi diri sendiri sejak tertangkap polisi atau BNN langsung dimasukkan ke tempat rehabilitasi. Selama proses hukum berlangsung sampai penjatuhan vonis oleh mejelis hakim tetap berada di tempat rehabilitasi untuk menjalani perawatan dan pemulihan ketergantungan obat.

Sebelum UU Narkotika, terkait kriminalisasi pengguna narkoba (Pasal 127 Ayat 1 UU Narkotika), diubah melalui pengajuan Judicial Review ke Mahkamah Konstitusi, atau lewat pengajuan perubahan Undang Undang oleh pemerintah kepada lembaga legislatif (DPR-RI), maka hakim dalam memutus perkara kasus narkoba dapat melakukan terobosan hukum dengan mencantumkan salah satu diktum dalam amar putusan untuk memerintahkan terdakwa melakukan pengobatan dan rehabilitasi. Hal ini sebagaimana telah diamanatkan dalam Pasal 54 dan Pasal 103 UU Narkotika dan juga berdasarkan SEMA Nomor 4 Tahun 2010 dan Peraturan Pemerintah Nomor 25 Tahun 2011.

Korban pengguna narkoba yang telah ditangkap pihak kepolisian atau institusi berwenang (BNN) tidak sepatutnya dimasukkan ke dalam rutan atau sel polisi, tetapi langsung ditempatkan di tempat rehabilitasi. Adapun pada saat proses pemeriksaan perkara sejak dari tingkat penyelidikan sampai di persidangan (criminal justice system), korban pengguna narkoba masih tetap ditempatkan di tempat rehabilitasi. Jika dalam persidangan terbukti hanya sebagai pengguna narkoba bagi dirinya sendiri, maka seyogianya hakim memberikan vonis bebas dengan ketentuan direhabilitasi sampai benarbenar sembuh. Hal ini berlaku selama Pasal 127 UU Narkotika belum diubah ataupun dicabut.

Untuk menerapkan model pemidanaan, sebagaimana dijelaskan di atas sebenarnya tidaklah sulit. Sebab perangkat hukum telah tersedia melalui UU Narkotika (Pasal 54, Pasal 103 dan Pasal 127 ayat (2) dan (3)) maupun amanat Mahkamah Agung melalui SEMANomor 4 Tahun 2010 ke dalam Lembaga Rehabilitasi Medis dan Sosial, yang menjadi pegangan bagi hakim pengadilan negeri dan pengadilan tinggi dalam memutus perkara. Selain itu, masih ada dua peraturan pemerintah yang mampu dijadikan landasan dalam menerapkan model yang ideal, yaitu Peraturan Pemerintah Nomor 25 Tahun 2011 dan Peraturan Kepala BNN Nomor 2 Tahun 2011.

\section{Membangun Paradigma Dekriminalisasi Korban Pengguna Narkoba}

Mencermati perkembangan di beberapa negara, muncul paradigma baru dalam memandang pengguna/pecandu narkoba yang tidak lagi dipandang sebagai perilaku jahat (kriminal) tetapi sebagai orang yang pengidap penyakit kronis yang harus mendapatkan perawatan dan pemulihan secara bertahap. Paradigma ini selanjutnya menciptakan kebijakan baru dalam menangani korban pengguna narkoba yang tidak lagi diproses secara hukum, tetapi langsung membawa pengguna/pecandu ke pusat rehabilitasi. Dengan kata lain paradigma ini mengarah pada upaya dekriminalisasi bagi pengguna narkoba.

Penerapan hukum pidana berupa pidana penjara bagi korban pengguna narkoba terbukti tidak berhasil, yang sesungguhnya terjadi justru setiap tahun korban pengguna narkoba yang dijatuhi pidana penjara angkanya semakin naik. Hal inilah yang perlu dikaji ulang terkait tujuan dan fungsi penerapan hukum pidana bagi korban pengguna narkoba. Faktor terpenting dalam upaya penanggulangan penyalahgunaan 
narkoba yang justru seringkali diabaikan terutama oleh aparat penegak hukum di Indonesia adalah adanya upaya rehabilitasi. Model pemidanaan terhadap korban pengguna narkoba sampai sekarang ini masih menempatkan sebagai pelaku tindak pidana (kriminal), sehingga upaya-upaya rehabilitatif sering terabaikan.

Sementara itu, jika dilihat perkembangan perlakuan bagi pecandu narkoba di beberapa negara, telah terjadi kecenderungan yang terus mengalami perubahan. Pada tahun 1980an, tren kebijakan global mengarah pada pendekatan kriminalisasi yang lebih keras, bahkan di tingkat pengguna. Dalam beberapa tahun terakhir ini, pembuat kebijakan obat dunia telah berusaha untuk merumuskan dan merekomendasi kebijakan tentang bagaimana cara terbaik untuk mengelola masalah yang berhubungan dengan narkoba secara eksklusif berdasarkan alasan empiris, salah satunya dengan cara dekriminalisasi atau depenalisasi terhadap pecandu narkoba. Meskipun begitu, kedua istilah tersebut memiliki bentuk kerja berbeda.

Pada tahun 2005, Badan Pemerintah Pusat Uni Eropa yang mengkoordinasikan data kebijakan obat, European Monitoring Centre for Drugs and Drug Addiction (EMCDDA), mengumumkan perbedaan definisi antara "dekriminalisasi" dan "depenalisasi" sebagai berikut.

"Decriminalisation" comprises removal of a conduct or activity from the sphere of criminal law. Prohibition remains the rule, but sanctions for use (and its preparatory acts) no longer fall within the framework of the criminal law. (By contrast) "Depenalization" means relation of the penal sanction provided for by law. In the case of drugs, and cannabis in particular, depenalization generally signifies the elimination of custodial penalties.

Singkatnya, "dekriminalisasi" berarti hanya salah satu sanksi non-criminal (seperti denda atau persyaratan pengobatan) yang dikenakan atau tidak ada sanksi pidana. Sementara dalam kerangka kerja "depenalisasi", penggunaan obat tetap menjadi pelanggaran pidana, tetapi hukuman penjara tidak lagi dikenakan atas kepemilikan atau penggunaan bahkan ketika sanksi pidana lain (misalnya, denda, catatan polisi, masa percobaan) tetap dimungkinkan (Glenn Greenwald, 2009:2). Dalam kerangka dekriminalisasi, penggunaan dan kepemilikan obat tetap dilarang (illegal) dan masuk dalam sasaran intervensi pihak kepolisian. Namun "dekriminalisasi" berarti bahwa pelanggaran telah dihapus sepenuhnya dari kerangka hukum pidana dan sistem peradilan pidana. Sebaliknya, pelanggaran itu dimasukkan ke dalam pelanggaran administrasi murni, yang selanjutnya diproses sebagai masalah nonkriminal.

Di beberapa negara Uni Eropa telah mengembangkan depenalisasi secara formal ataupun secara de facto, khususnya untuk penggunaan pribadi atas ganja. Tetapi tidak ada negara di Uni Eropa selain Portugal yang telah secara eksplisit menyatakan "dekriminalisasi" terhadap pecandu narkoba. Ketika negara lain di Uni Eropa mengembangkan berbagai bentuk dekriminalisasi secara de facto, yang dalam hal ini menempatkan zat yang dianggap tidak terlalu berbahaya (seperti ganja) jarang menyebabkan causa penuntutan kriminal. Portugal adalah satu-satunya negara yang secara terang-terangan menyatakan obat terlarang "didekriminalisasikan". Karena lebih dari tujuh tahun sejak diberlakukannya sistem dekriminalisasi di Portugal, ada banyak data yang memungkinkan untuk menilai dampakdampaknya.

Dekriminalisasi telah menjadi semakin populer di Portugal khususnya sejak 2001, kecuali untuk beberapa politisi aliran kanan, sangat sedikit faksi politik domestik yang mendorong pencabutan produk hukum tahun 2001 itu. Ketika ada persepsi yang meluas bahwa perubahan birokrasi perlu dilakukan terkait kerangka kerja dekriminalisasi Portugal agar lebih efisien dan efektif, tidak ada perdebatan tentang apakah obat harus dikriminalisasi. Lebih penting lagi, kekhawatiran yang didengungkan oleh penentang dekriminalisasi sebelum diundangkan -dari peningkatan besar dalam penggunaan obat di kalangan anak muda sampai perubahan Lisbon menjadi tempat berlindung bagi "wisatawan obat" tidak terjadi (Caitlin Hughes and Alex Stevens, 2007: 20).

Konsensus politik yang mendukung dekriminalisasi tidaklah mengejutkan, mengingat data empiris terkait. Data tersebut menyebutkan bahwa dekriminalisasi tidak berpengaruh tingkat penggunaan obat di Portugal, yang dalam banyak kategori, sekarang termasuk yang terendah di Uni Eropa, terutama bila dibandingkan dengan negara-negara yang menerapkan kriminalisasi ketat.

Selain Portugal, di beberapa negara Uni Eropa lainnya juga telah mengadopsi sistem dan paradigma yang mirip dengan dekriminalisasi 
secara de facto, tetapi belum secara eksplisit menyatakan dekriminalisasi atas penggunaan obat. Spanyol misalnya, undang-undang yang diterapkan, "The Law on Protection of Citizens Security " menyebutkan, seseorang yang mengonsumsi narkoba di depan umum dianggap sebagai pelanggaran serius dan dikenakan sanksi administratif yang umumnya berupa sanksi denda. Tetapi sanksi tersebut dapat ditangguhkan jika pengguna tersebut bersedia mengikuti program terapi. Selain itu, terdapat celah hukum obat di Spanyol yaitu konsumsi obat publik dilarang, tetapi penggunaan obat secara personal tidak dilarang. Sementara untuk kasus perdagangan, Undang-Undang Narkotika Spanyol menetapkan hukuman yang cukup berat, khususnya penjualan kepada anak-anak di bawah usia 18 tahun, atau dalam jumlah besar melebihi 500 dosis (over 500 doses) (http:// www.drugwarfacts.org/cms/Spain).

Bentuk lain dari dekriminalisasi secara de facto telah ditetapkan di Jerman, dalam hal ini pengadilan memutuskan bahwa hukuman penjara karena pelanggaran memiliki obat terlarang dalam jumlah yang banyak berpengaruh terhadap masalah konstitusional. Sementara di Luksemburg dan wilayah lain di Jerman Utara, hanya memberlakukan hukuman denda untuk penggunaan ganja (marijuana), dan kasus yang masuk ke pengadilan hanya melibatkan perdagangan narkoba dalam jumlah besar (http://www.ehow.com/list_6907015_ german- marijuana-laws.html).

Belanda menjadi salah satu negara Eropa, bahkan dapat dikatakan sebagai negara "modern" pertama yang melegalkan penggunaan narkoba untuk diri sendiri. Narkoba memang dilegalkan di Belanda, bahkan di Kota Amsterdam ada semacam coffee house yang isinya juga menjual ganja, dan orang-orang yang berada di dalamnya boleh bebas menggunakan ganja. Kebiasaan menggunakan narkoba ini disebabkan karena Belanda memiliki tradisi panjang dalam penggunaan dan pemanfaatan narkoba (P Cohen, 1990: 4).

Undang-Undang Narkotika Belanda (Opium Art) memberikan ketegasan bahwa ekspor dan impor narkoba adalah kejahatan yang paling serius. Hukuman maksimal untuk kegiatan ekspor dan impor hard drugs adalah 12 tahun penjara dan denda Dfl. 100.000. Sedangkan hukuman maksimal untuk kegiatan impor dan ekspor soft drugs adalah 4 (empat) tahun penjara dan denda Dft. 100.000. Residivis dapat dikenakan hukuman maksimal 16 tahun penjara dan denda Dft.
1.000.000. Kepemilikan narkoba pada semua bagian adalah tindak pidana, namun kepemilikan yang sedikit dari jenis soft drugs untuk penggunaan pribadi dianggap bukan tindak pidana, bahkan diperbolehkan oleh hukum sejak diaturnya coffee shop system.

Pada awal tahun 1980-an, diadakan sebuah riset mengenai tipologi penggunaan narkoba. Riset ini kemudian memicu pembangunan kebijakan narkoba Belanda. Riset tersebut melahirkan konsep normalization atau cultural integration. Konsep ini lahir dari sejarah yang menunjukkan bahwa penggunaan narkoba ada dan bersamaan dengan kebudayaan manusia. Oleh karena itu pecandu narkoba tidak harus diperlakukan seperti seorang penjahat ataupun pasien ketergantungan, akan tetapi harus diperlakukan secara normal seperti orang biasa (Hen Jan van Vliet, 1990:173).

Adapun Cina pengguna narkoba yang telah berada di atas 5 juta tercatat di semua tempat pengobatan di rumah sakit subdistrik atau kecamatan dan rumah sakit umum. Karena Cina tidak mengadopsi sistem pengobatan barat, maka kebijakan yang diterapkan lebih bersifat memaksa dalam hal penghentian pemakaian narkoba. Ada tiga macam pusat rehabilitasi narkoba di China. Pertama, pusat rehabilitasi narkoba yang dikelola oleh polisi. Kedua, pusat rehabilitasi narkoba dengan melakukan kerja sosial, dan dikelola oleh Departemen Hukum. Ketiga, pusat rehabilitasi narkoba yang dikelola oleh Departemen Kesehatan (Z Yongming, 1999:830). Dalam praktiknya, para pengguna narkoba akan dikirim ke pusat penanggulangan narkoba, dan jika terungkap menggunakan lagi akan dikirim ke pusat-pusat rehabilitasi dan harus melakukan kerja-kerja sosial.

Namun demikian, apabila setelah menjalani pengobatan di rumah sakit atau tempat rehabilitasi sosial dan medis, ternyata masih menggunakan narkoba di rumah, maka harus ada pembinaan lebih lanjut dari pemerintah. Mantan pecandu narkoba yang telah sembuh dan mendapat penyuluhan, kemudian diarahkan untuk melaporkan keberadaan para pengedar atau penjual yang telah mendatangi atau berusaha memberinya narkoba.

Menelaah persoalan hukum pidana yang mengatur tentang narkoba terdapat juga upayaupaya untuk mendorong penanganan pengguna narkoba dalam kedudukannya sebagai korban. Sejalan dengan ketentuan ini, 
Hungaria telah menerapkannya, yaitu apabila pengguna narkoba tertangkap karena penggunaan narkoba maka pengguna akan diperiksa di kantor polisi dan kemudian dokter didatangkan untuk memeriksa apakah tersangka adalah pengguna narkoba atau tidak. Bila tersangka adalah seorang pengguna narkoba, terutama telah mencapai tahap kecanduan, maka tersangka diberikan pilihan apakah mau dipenjara atau menjalani rehabilitasi. Apabila memilih rehabilitasi, maka pengguna akan dirujuk ke klinik rehabilitasi yang telah tersedia. Pada posisi demikian, para pengguna narkoba jelas diberikan kesempatan untuk memilih haknya sebagai korban.

Hal yang sama juga terjadi di Malaysia, Pemerintah Malaysia telah menyatakan narkoba sebagai musuh nomor satu negara sejak tahun 1973 ketika hukuman mati dicantumkan terhadap pelaku transaksi perdagangan narkoba. Meskipun demikian, pengguna narkoba di Malaysia terus bertambah, sebelum akhirnya pemerintah membuat strategi menanggulangi narkoba. Sepanjang 2002, sebanyak 31.893 orang pecandu narkoba telah terdeteksi oleh pihak otoritas Agensi Dadah Kebangsaan/ADK (semacam Badan Narkotika Nasional). Data yang dirilis tahun 2003 sebanyak 26.190, tahun 2004 sekitar 26.775, dan 2005 per Februari sebanyak 7.968. Adapun menurut data ADK hingga Maret 2006 terdapat 292.696 pecandu narkoba. Organisasi non-pemerintah (NGO) juga memperkirakan terdapat sekitar 350.000 orang yang terlibat narkoba. Angka ini dikatakan bertambah sebanyak 1.300 pecandu narkoba setiap bulan (Datuk Seri Abdullah Bin Haji Ahmad Badawi, 2003). Untuk menurunkan para pengguna, pemerintah Malaysia telah merubah strategi dalam penanggulangan kasus pecandu narkoba yang semula memfokuskan pada aspek penegakan hukum pidana kepada pendekatan memerangi penyakit kecanduan dengan cara perawatan atau rehabilitasi dengan menerbitkan Akta Penagih Dadah (Rawatan dan Pemulihan) 1983 - Pindaan 1998 (Mahmood Nazar Mohamed, 2003: 28).

Para pengguna narkoba (dadah) yang terbukti melakukan tindak pidana narkoba di depan pengadilan, maka hakim wajib memutuskan pengguna/pecandu narkoba untuk menjalani rehabilitasi. Ketentuan ini berlaku juga apabila pecandu tersebut dipidana untuk kedua kalinya atas perkara yang sama dan apabila melakukan tindak pidana narkoba untuk ketigakalinya, barulah hakim diperbolehkan memutuskan pecandu untuk dipenjara untuk menimbulkan efek jera. Negara terakhir yang hendak melakukan dekriminalisasi pengguna narkoba adalah Kolombia. RUU Dekriminalisai Penggunaan narkoba merupakan tindak lanjut dari keputusan Mahkamah Agung Kolombia bahwa kepemilikan narkoba dalam jumlah kecil merupakan hak yang dilindungi oleh konstitusi.

Kolombia adalah negara pertama di Amerika Selatan yang memperbolehkan konsumsi narkoba untuk keperluan pribadi, ketika negara tersebut mendekriminalisasi kepemilikan narkoba dalam jumlah kecil pada 1994. Mantan Presiden Kolombia Alvaro Uribe, kemudian membatalkan keputusan legalisasi tersebut, tetapi kemudian keputusan Presiden Uribe dinyatakan tidak berlaku oleh Mahkamah Agung Kolombia. RUU Narkotika Kolombia mengusulkan batas kepemilikan personal sejumlah 5 gram ganja, dan 1 (satu) gram kokain. RUU juga mengusulkan batas kepemilikan personal untuk jenis narkoba yang belum disetujui oleh keputusan Mahkamah Agung, yaitu metamfetamin dan ekstasi.

Presiden saat ini Juan Manuel Santos berulangkali menyerukan analisa ulang kebijakan "perang terhadap narkoba" dan menyambut baik keputusan Amerika Serikat untuk mendiskusikan kemungkinan kebijakan alternatif pada pertemuan pembahasan narkoba bagi seluruh Amerika di Kartagena. Pada saat yang sama presiden telah menyatakan kepada pers internasional bahwa ia mendukung diskusi mengenai legalisasi narkoba (http://www.druglawreform.info/en/ country-information/colombia), dan mendapat dukungan dari mantan presiden César Gaviria yang sekarang ini telah menjadi bagian dari komisi global yang pendukung dekriminalisasi konsumsi narkoba.

Ketika China, Hungaria, Malaysia, Spanyol dan beberapa negara lain termasuk Australia, telah memperlakukan pengguna narkoba sebagai korban meskipun tetap diancam dengan hukuman. Tetapi bagi pengguna yang membawa narkoba di bawah ketentuan (misalnya membawa sabu-sabu di bawah 2 gram) tidak langsung dibawa ke rumah tahanan polisi, tetapi diserahkan ke pihak rehabilitasi untuk menjalani perawatan. Apabila seseorang kedapatan menggunakan untuk kedua kalinya, pihak kepolisian memerintahkan pengguna untuk menjalani perawatan dan melakukan kerja sosial di instansi-instansi pemerintah atau membantu pekerjaan orang tua. Perawatan dan pemantauan terus dilakukan, sehingga masa 
menjalani perawatan benar-benar mendapat perhatian.

Di Indonesia pola semacam itu belum diterapkan, korban pengguna narkoba masih dimasukkan ke dalam penjara, meskipun selama proses tahanan diperkenankan untuk direhabilitasi, namun belum menjadi solusi efektif. Sistem hukum di Indonesia harus mulai melakukan kebijakan dengan langsung membawa korban pengguna narkoba ke tempat rehabilitasi. Apabila korban pengguna narkoba ditangkap polisi atau dilaporkan orang tua dan/atau wali maka mereka harus ditempatkan di tempat rehabilitasi.

Namun demikian, usaha Pemerintah Indonesia menuju dekriminalisasi korban pengguna narkoba sebenarnya telah dimulai dengan dikeluarkannya SEMANomor 7 Tahun 2009 yang kemudian diganti dengan SEMA Nomor 4 Tahun 2010 tentang Penempatan Penyalahgunaan, Korban Penyalahgunaan dan Pecandu Narkotika ke dalam Lembaga Rehabilitasi Medis dan Rehabilitasi Sosial, yang secara substansial kedua SEMA tersebut tidak ada perubahan. Perbedaan kedua SEMA tersebut hanya terletak pada jumlah barang bukti saja. Pemerintah juga telah mengeluarkan Peraturan Pemerintah Nomor 25 Tahun 2011.

Keluarnya SEMA Nomor 4 Tahun 2010 dan Peraturan Pemerintah Nomor 25 Tahun 2011 ini sebenarnya mengukuhkan bahwa pecandu narkoba adalah korban dan bukan pelaku tindak kriminal, sekaligus menjadi legitimasi hukum bahwa pecandu bukanlah pelaku tindak kejahatan melainkan seseorang yang menderita sakit karena kecanduan membutuhkan perawatan baik secara fisik maupun secara psikologis serta membutuhkan dukungan dari masyarakat untuk dapat kembali hidup normal.

Beberapa pejabat negara seperti Kapolri Jenderal Timur Pradopo juga memiliki gagasan yang sama, menurutnya paradigma untuk menempatkan korban pengguna narkoba ke tempat rehabilitasi sebenarnya telah lama disuarakan dan telah ditetapkan dalam Undang-Undang Narkotika, dan dalam SEMA Nomor 4 Tahun 2010, tetapi dalam implementasinya belum banyak dilakukan, sehingga sampai sejauh ini korban pengguna narkoba masih harus menjalani proses pengadilan. Para korban pengguna narkoba, menurutnya tidak perlu ditangkap atau dihukum, tetapi para pengguna narkoba lebih perlu diberikan pengobatan di pusat rehabilitasi. Kalau para pengguna narkoba justru ditahan atau dihukum, tidak akan membuat efek jera, bahkan semakin bandel (Parasian Simanungkat, 2011: iv).

Kewajiban menjalani rehabilitasi bagi korban pengguna narkoba dimaksudkan untuk mengurangi jumlah pangsa pasar narkoba di Indonesia, sehingga nantinya diharapkan terjadi keseimbangan antara faktor supply dan demand reduction. Kebijakan dan strategi yang dilakukan pemerintah untuk mengurangi permintaan narkoba adalah dengan melakukan rehabilitasi kepada seluruh pecandu, meningkatkan imunitas masyarakat, serta meningkatkan upaya pemberdayaan terhadap masyarakat. Adapun strategi untuk mengurangi jumlah ketersediaan narkoba dilakukan melalui upaya pemberantasan atau penegakan hukum terhadap jaringan peredaran narkoba.

Selain itu, ketentuan dikeluarkan SEMA ini juga karena umumnya pengambilan kebijakan di Indonesia saat ini masih menganut sistem public security dan belum pada tahap public health. Artinya, upaya yang dilakukan di Indonesia saat ini masih dominan terhadap bidang pemberantasan penyalahgunaan narkoba, atau belum memfokuskan pada upaya merehabilitasi pecandu dari aspek medis dan sosial. Keberadaan SEMA Nomor 4 Tahun 2010 merupakan rujukan untuk membedakan terdakwa sebagai penyalahguna/pecandu atau sebagai pengedar/bandar dengan standar minimal barang bukti yang didapatkan. Barang bukti hanyalah salah satu alat bukti, sedangkan pembuktian minimal ada dua alat bukti, jika di dalam proses peradilan terbukti adanya tindak peredaran yang dilakukan terdakwa meskipun barang bukti narkoba yang dimiliki di bawah minimal tentu saja sah apabila hakim menjatuhkan vonis sebagai pengedar/bandar.

Dengan ketentuan tersebut dunia peradilan di Indonesia sebetulnya telah membuka mata tentang hakikat pecandu narkoba dalam konteks ilmu hukum khususnya viktimologi. Sesuatu yang sangat sulit dilegitimasi selama ini, sehingga selama "perang terhadap narkoba" dikumandangkan oleh pemerintah Indonesia, pecandu narkoba selalu ditempatkan sebagai kriminal, maka hak-hak korban untuk mendapatkan pelayanan kesehatan dan perlakuan khusus, dalam hal ini rehabilitasi menjadi hilang. Tantangan ke depan justru berada dalam pundak hakim untuk berani memutus atau menetapkan vonis rehabilitasi terhadap pecandu dan melakukan terobosan hukum serta penemuan hukum yang tidak hanya mengacu pada undang-undang 
saja, tetapi lebih pada nilai-nilai sosial dan kemanusiaan yang hidup dalam masyarakat. Tantangan lain bagi pembuat kebijakan adalah apakah kekuatan surat edaran dari aspek yuridis formal mampu mendekriminalsiasi pecandu kerena dari beberapa sumber menyebutkan negara yang mendukung dekriminalisasi secara de jure mencabut semua peraturan yang menghukum para pengguna dan dalam penanganannya tidak memenjarakan, menuntut ataupun melakukan penangkapan kepada pengguna. Oleh karena itu, untuk menguatkan dan meletakkan pengguna narkoba sebagai korban, maka hal pertama yang harus dilakukan oleh Pemerintah dan Dewan Perwakilan Rakyat Republik Indonesia (DPR-RI) adalah merevisi atau menghapus pasal-pasal dalam UndangUndang Narkotika yang mengkriminalisasikan korban pengguna narkoba. Adanya dekriminalisasi terhadap penyalahguna dan pecandu narkoba maka penegak hukum akan lebih fokus dalam menangkap pengedar yang merupakan pelaku kejahatan, dan memaksimalkan program rehabilitasi bagi pecandu narkoba karena para korban penyalahgunaan narkoba tidak lagi menyembunyikan diri dan merasa takut untuk dipidanakan.
Dengan demikian, model pemidanaan terhadap korban penyalahgunaan narkoba harus berorientasi pada penyembuhan dan pemulihan, baik melalui lembaga-lembaga medis (rumah sakit dan puskesmas), maupun lembaga sosial. Sehingga melahirkan model berupa penanganan yang dapat diterapkan terhadap korban pengguna narkoba. Bentuk penanganan bagi korban pengguna narkoba dapat dilakukan melalui jalur medis (instansi tempat lapor) dan lewat aparat penegak hukum (law enforcement). Jalur medis dalam artian pemerintah menyediakan tempat lapor di masing-masing provinsi, kabupaten/kota maupun kecematan di seluruh Indonesia untuk mencatat dan melaporkan adanya korban pengguna atau pecandu narkoba kemudian membawanya ke pusat-pusat rehabilitasi. Sementara bagi penegak hukum, kepolisian dan/atau BNN sebagai institusi yang memiliki kewenangan berhak menangkap yang selanjutnya membawa langsung korban atau pecandu narkoba yang belum melapor untuk berobat di tempat rehabilitasi sampai sembuh.

Berikut ini usulan format model penanganan korban pengguna narkoba setelah terjadinya perubahan dalam Undang Undang Narkotika.

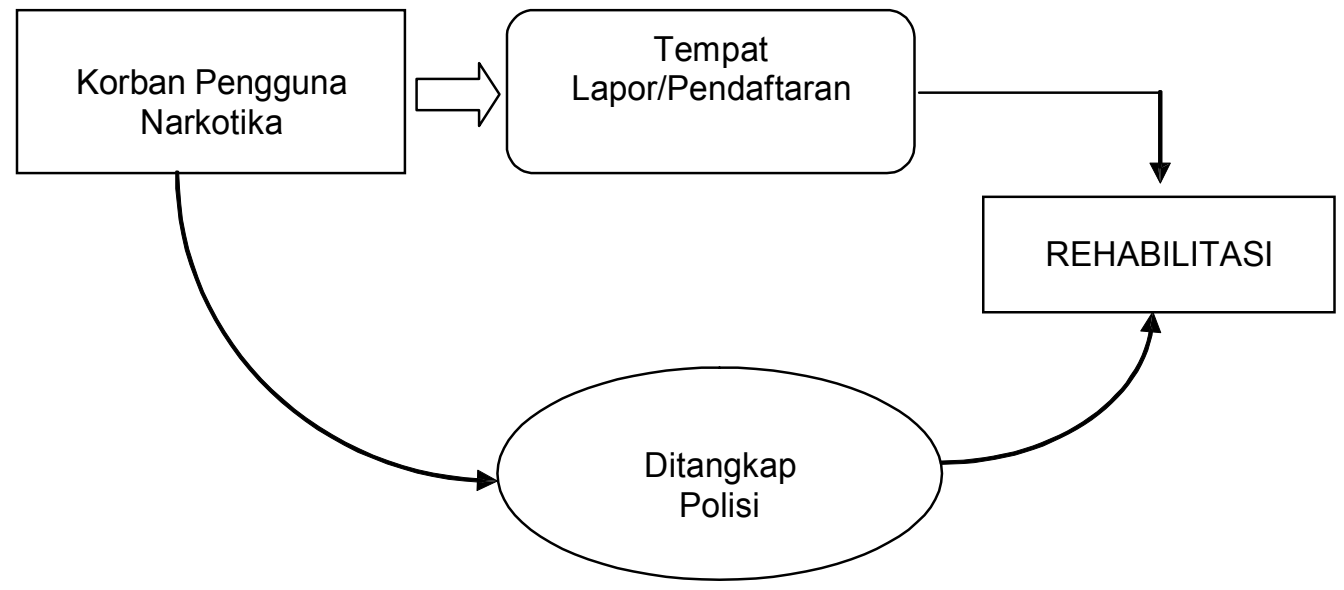

Gambar 1. Model Penanganan Korban Pengguna Narkoba

Korban pengguna narkoba dengan suka rela datang mendaftarkan diri untuk berobat ke tempat rehabilitasi yang telah ditunjuk oleh pemerintah. Korban pengguna narkoba yang tidak mau melaporkan diri, pihak kepolisian dan BNN berhak untuk menangkap dan membawanya ke tempat rehabilitasi untuk berobat sampai sembuh.
Mengingat banyaknya korban pengguna narkoba yang akan direhabilitasi, maka diperlukan biaya yang cukup besar. Pendanaan pelaksanaan rehabilitasi bagi pecandu narkoba yang tidak mampu menjadi tanggung jawab pemerintah yang menurut Pasal 101 ayat (3) UU Narkotika, dihasilkan dari harta kekayaan atau harta benda yang 
merupakan hasil tindak pidana dan hasil pencucian uang dari tindak pidana narkoba dan prekursor narkoba berdasarkan putusan pengadilan yang telah memperoleh kekuatan hukum tetap dirampas untuk negara dan digunakan untuk kepentingan pelaksanaan pencegahan dan pemberantasan penyalahgunaan peredaran gelap narkoba dan prekursor narkoba, dan sebagai upaya rehabilitasi medis dan sosial. Adanya penanganan yang baik dari pihak rumah sakit atau tempat rehabilitasi, dan didukung lingkungan yang sehat, maka korban pengguna narkoba akan lebih cepat pulih dan mampu beradaptasi kembali dengan masyarakat, dan turut serta membangun bangsa dan negara. Selain itu, upaya ini juga dimaksudkan untuk mewujudkan rencana pemerintah membebaskan Bangsa Indonesia dari penyalahgunaan narkoba, dan peredaran gelap narkoba, sehingga tidak ada lagi korban yang meninggal akibat penyalahgunaan narkoba.

\section{Simpulan}

Berdasarkan hasil penelitian dan pembahasan dapat ditarik simpulan bahwa dalam menangani kasus narkoba, khususnya korban maupun pecandu, hakim di Indonesia dapat dikatakan jarang sekali melakukan terobosan hukum yang menitikberatkan pada nilai-nilai sosial dan kemanusian yang hidup dalam masyarakat. Hakim di Indonesia hanya melihat sisi pidana dalam Undang Undang tanpa melihat efek negatif keputusan tersebut, akibatnya pidana penjara hanya dilihat sebagai pemberian efek jera bagi pelaku tindak pidana. Korban pengguna narkoba menurut Undang Undang Narkotika diputus hukuman pidana penjara karena pengguna narkoba diklasifikasi sebagai pelaku tindak pidana. Hal ini bertentangan dengan teori hukum tentang viktimologi (korban). Beberapa negara telah membuktikan bahwa kebijakan dekriminalisasi memiliki pengaruh terhadap penurunan penyalahgunaan narkoba. Model pemidanaan yang ideal bagi korban pengguna narkoba adalah proses di luar proses hukum yaitu semua korban pengguna narkoba melaporkan diri untuk direhabilitasi. Sementara bagi yang tidak melaporkan diri, polisi dan/atau BNN melakukan penangkapan dan langsung diantar dan diserahkan ke tempat rehabilitasi.

\section{E. Saran}

Berdasarkan hasil penelitian dan pembahasan, dan simpulan disarankan kepada pihak-fihak di bawah ini sebagai berikut.

1. Pemerintah bersama DPRI-RI perlu segera mengubah Undang Undang Narkotika, khususnya pasal-pasal yang masih memposisikan pengguna narkoba sebagai pelaku kriminal, sehingga pada masa mendatang pengguna narkoba tidak lagi sebagai pelaku kriminal melainkan sebagai korban dari kejahatan peredaran narkoba.

2. Kementerian Kesehatan agar menyiapkan pusat-pusat rehabilitasi, baik berupa rumah sakit maupun puskesmas yang menangani secara khusus korban pengguna narkoba. Selain itu, pemerintah perlu mendorong semua komponen bangsa untuk berperan serta mendirikan tempat rehabilitasi yang dapat dijadikan rujukan bagi pengguna atau pecandu narkoba.

3. Polisi, BNN dan juga Kejaksaan agar tidak memasukkan korban pengguna narkoba ke rumah tahanan negara tetapi langsung menempatkan ke tempat rehabilitasi untuk mendapatkan pengobatan sambil menunggu revisi UU Narkotikam aupun peraturan lainnya yang mendukung kebijakan tersebut. 


\section{Daftar Pustaka}

Aaron T. Beck. 1993. Cognitive Therapy of Substance Abuse. New York: The Guilford Press.

Abidin Az, Andi Hamzah. 2010. Hukum Pidana Indonesia. Jakarta: PT. Yasrif Watampone.

Anonim. 1997. Undang-Undang Nomor 5 Tahun 1997 tentang Psikotropika.

. 1999. Undang-Undang Nomor 39 tahun 1999 tentang Hak Asasi Manusia.

2004. Undang-Undang Nomor 4 Tahun 2004 tentang Kekuasaan Kehakiman.

2006. Undang-Undang Nomor 13 Tahun 2006 tentang Perlindungan Saksi dan Korban. 2009. Undang-Undang Nomor 35 Tahun 2009 tentang Narkotika

A.R. Sujono dan Bony Daniel. 2011. Komentar dan Pembahasan Undang-Undang Nomor 35 Tahun 2009 Tentang Narkotika. Jakarta: Sinar Grafika.

Dikdik M Arief Manshur dan Elisatris Gultom. 2007. Urgensi Perlindungan Korban Kejahatan. Jakarta: PT Raja Grafindo Persada.

Glenn Greenwald. 2009. Drug Decriminalization in Portugal; Lessons for Creating Fairand Successful Drug Policies. USA: Cato Institute

Hen Jan van Vliet. 1990. The Uneasy Decriminalization: A Perspective on Dutch Drug Policy. Dutch: Hofstra Law Review

Howard Abadinsky. 2008. Drug Use and Abuse: A Comprehensive Introduction. USA:. Wadsworth

Hughes Caitlin dan Alex Stevens. 2007. "The Effects of Decriminalization of Drug Use in Portugal". The

Beckley Foundation Drug Policy Pragramme.

http://www.unodc.org/treatment/en/China_Shanghai_resource_centre.html (3 Maret 2012)

http://www.druglawreform.info/en/country-information/colombia, "Summary overview of drug-laws and legislation trends in Colombia". [3 Maret 2012].

http://www.drugwarfacts.org/cms/Spain. [3 Maret 2012].

http://www.satuportal.net. [20 Juni 2011].

J.E. Sahetapy (editor). 1995. Bunga Rampai Viktimisasi. Bandung : Eresco

Mahmood Nazar Mohamed. 2003. Mencegah, Merawat dan Memulihkan Penagih Dadah: Beberapa Pendekatan dan Amalan di Malaysia. Kuala Lumpur: Utusan Publication \& Distributors Sdn Bhd

P Cohen. 1990. Drugs as a Social Construct. Amsterdam: University of Amsterdam.

Parasian Simanungkalit. 2011. Globalisasi Peredaran Narkotika dan Penanggulangannya di Indonesia. Jakarta:Yayasan Wajar Hidup.

Soedarto. 2007. Hukum dan Hukum Pidana. Bandung: PT Alumni:

Tongat. 2008. Dasar-Dasar Hukum Pidana Indonesia dalam Perspektif Pembaharuan. Malang : UMM Press.

Yongming, Z. 1999. Anti-Drug Crusades in Twentieth Century China: Nationalism, History and State Building. Lanham MD: Rowan and Littlefield. 